\title{
Seroprevalence of Herpes Simplex Virus Type-1 IgG Antibody in Healthy Blood Donor from Baghdad, Iraq
}

\author{
Arwa Mujahid Abdullah Al-Shuwaikh ${ }^{1 *}$ (D) Dalya Basil Hanna ${ }^{2}$ and Zahraa \\ Qasim Ali ${ }^{3}$ \\ ${ }^{1}$ Department of Microbiology, College of Medicine, Al-Nahrain University, Baghdad, Iraq. ${ }^{2}$ Depatment of Clinical \\ Laboratory Sciences, College of Pharmacy, Mustansiriyah University, Baghdad, Iraq. ${ }^{3}$ Department of Anatomy, \\ Histology Section, College of Medicine, Baghdad University, Baghdad, Iraq.
}

\begin{abstract}
Herpes simplex virus type 1 (HSV-1) is a common infectious agent worldwide. It can cause earnest illnesses at each stage of life. Data on seroprevalence of HSV-1 antibody (Ab) in Iraqi population is limited. This study aimed on determination the frequency of HSV-1 IgG Ab in apparently healthy blood donor of Baghdad province, capital of Iraq. In this study, serum samples were collected from 454 apparently healthy blood donor (385 male and 69 female), their ages ranged from 18 to 64 year. This study was conducted through the period from October, 2018 to February, 2019. Demographic data were gathered by a well-designed questionnaire. Five (5) $\mathrm{ml}$ of blood sample was collected and centrifuged, all obtained sera samples were tested using Enzyme linked Immunosorbent Assay (ELISA) for determine of HSV-1 IgG Ab. Totally, HSV-1 IgG Ab were positive in 427 out of 454 (94.1\%) among studied population. The age groups of (21-30) years and (31-40) years had the highest percentage of seropositivity for anti HSV-1 IgG Ab (39.1\% and 32.3\%, respectively), while the lowest seropositivity was found in age groups $(>50)$ years and $(\leq 20)$ years $(4.4 \%$ and $5.4 \%$, respectively). The frequency of HSV-1 IgG Ab was higher among male (84.8\%) compared with females (15.2\%), however, it was not statistically significant $(P>0.05)$. Results confirm a high frequency of anti HSV-1 IgG Ab among Iraqi population. The high frequency of HSV-1 infection underlines the need for focusing on preventive efforts and education among the population about HSV-1 and its complications.
\end{abstract}

Keywords: HSV-1, ELISA, adult, blood donor, Iraq.

\footnotetext{
*Correspondence: arwa.mujahid@colmed-alnahrain.edu.iq

(Received: 01 April 2019; accepted: 17 May 2019)

Citation: Arwa Mujahid Abdullah Al-Shuwaikh Dalya Basil Hanna and Zahraa Qasim Ali, Seroprevalence of Herpes Simplex Virus Type-1 IgG Antibody in Healthy Blood Donor from Baghdad, Iraq, J Pure Appl Microbiol., 2019; 13(2):1017-1023. doi: 10.22207/ JPAM.13.2.39

(c) The Author(s) 2019. Open Access. This article is distributed under the terms of the Creative Commons Attribution 4.0 International License which permits unrestricted use, sharing, distribution, and reproduction in any medium, provided you give appropriate credit to the original author(s) and the source, provide a link to the Creative Commons license, and indicate if changes were made.
} 


\section{INTRODUCTION}

Herpes simplex virus type 1 (HSV-1), a neurotropic member belong to the alpha herpes subfamily of the Herpesviridae, is an enveloped large dsDNA virus ${ }^{1}$. Herpes is derived from the Greek word "to creep" and this term used for the first time by Hippocrates to describe how this ulcerative lesion appear to be creeping along the $\mathrm{skin}^{2}$. However, the virus was not discovered till $1950 \mathrm{~s}^{3}$. HSV-1 is typically transmitted during childhood through nonsexual routes primarily through oral secretions or by contact with the infected region of the skin during virus reactivation ${ }^{4,5,6}$. Exposure to HSV-1 during childhood in western countries was diminished due to hygiene practice and improve the socioeconomic conditions, therefore; young people could reach sexual debut with no defensive antibodies against HSV-1 disease, and subsequently at risk of obtaining the infection genitally. Herpes simplex virus type- 1 may be transmitted vertically from the mother to the fetus, in spite of fact that, the hazard is very low ${ }^{8}$.

Herpes simplex virus type 1 infection can cause clinical disease in various parts of the human body, such as genitalia, eye, oral, and central nervous system (CNS) ${ }^{1}$. The HSV encephalitis considered the commonly occurring sporadic viral encephalitis with no seasonal pattern ${ }^{9}$. The primary infection of HSV-1 is mainly in epithelial or mucosal cells, and then establishes a latent infection when it is transported to the sensory ganglia ${ }^{10}$. The renewed lytic infection at epithelial or mucosal cells happens when there is reactivation of latent $\mathrm{HSV}-1^{11}$. Smoking, poor nutrition, physical emotional stress, fever, UVlight, trauma, burns, reactivational drug, radiation therapy or chemotherapy all of which cause stress that is diminish the immune system and lead to reactivation of latent infection ${ }^{12,13}$.

In adult, the rates of HSV-1 are ranged between $60 \%-90 \%{ }^{14}$. Geographic and socioeconomic diversities have brought about differences in HSV prevalence among various populations and regions ${ }^{4}$. In developing countries, HSV-1 infection is common and obtained from intimate contact with parents and family members in infancy but in developed countries, it was suggested that acquisition of HSV-1 is delayed from infancy to puberty ${ }^{1}$. The current treatment is effective only on replicating virus but doesn't work against latent infection; therefore, it will never terminate the virus ${ }^{13}$. Nowadays, there was no specific vaccine or immunization strategy for HSV- $1^{1}$.

The continuous alteration in community may affect the acquisition patterns of HSV that need continuous monitoring ${ }^{15}$. This study aimed to determine the frequency of HSV-1 IgG Ab among apparently healthy blood donor using ELISA technique. Since, the virus is orally transmitted in general-population; therefore, the seroprevalence among apparently healthy blood donor should reflect that in the wider population ${ }^{16,6}$. In addition, HSV-1 screening in blood bank in Iraq is not mandatory.

\section{MATERIALS AND METHODS}

\section{Study population and samples collection}

In this cross sectional study, blood samples were collected from 454 adults apparently healthy blood donors their ages were ranged between 18-64 year, 385 were male and 69 were female who attended the Blood Donation Center in Al-Imamain Al-Kadhimain Medical City Hospital and the National Blood Bank in Baghdad. Samples were centrifuged at (2000) rpm for $15 \mathrm{~min}$., then sera were separated and stored at $(-20)^{\circ} \mathrm{C}$ until tested by ELISA technique for determine of HSV$1 \mathrm{IgG} A b$. This study was conducted during the period from October, 2018 to February, 2019. The study was approved by the Institutional Review Board (IRB) at Al-Nahrain College of Medicine and consent was obtained from all participants before included in this study. Certain demographic data regarding age, gender, occupation, travel history and cupping practice were recorded.

\section{HSV-1 IgG-Ab detection}

All 454 samples were tested by indirect ELISA (Human Gesellschaft für Biochemica und Diagnostica, Germany) for HSV-1 IgG antibody detection. Sera were screened at 1:100 dilution, the procedure was done following manufacturer's instructions. Blank, positive and negative control was included with each run. The micro titer plate was coated with cell culture derived HSV antigen (HSV1-Ag). The HSV-1 IgG Ab present in patient serum bind to the antigen at the solid phase. At the end of the incubation, the unbound antibodies were washed out. Then a second rabbit anti-human $\lg \mathrm{Ab}$, which are conjugated with peroxidase 
are applied. Then after the second incubation step excess components were washed out to remove unbound conjugate. Then the reaction was visualized by the addition of the substrate 3,3,5,5- tetramethylbenzidin (TMB) with hydrogen peroxide and incubate in dark. At the end of the incubation blue color developed at the positive wells that converted to yellow color after addition of the of stopping reagent (sulphuric acid). The intensity of the color is directly proportional to the HSV1-IgG-Ab concentration in the specimen. The optical densities (O.D.) of each well were measured at wave length $(450 \mathrm{~nm}$ and reference filter 630 $\mathrm{nm}$ ) within half an hr. after the end of the reaction.

\section{Interpretation of results}

For Herpes simplex virus type 1 detection, the cut-off value was calculated by adding 0.1 multiplied by the mean absorbance values of positive control to the measured mean absorbance values of negative control. The net O.D. of each sample was considered positive if their absorbance reading is equal or lager than $15 \%$ above the calculated cut-off. While the samples with absorbance reading less than $15 \%$ below the calculated cut-off were considered negative. The results lying $15 \%$ above or below the cut-off value were considered equivocal. The equivocal samples should repeated in fresh sample taken 7 to 14 days later, therefore, all equivocal sample were excluded from this study.

\section{Statistical Analysis}

Data were analyzed using Statistical Package for the Social Sciences program (SPSS program, versions 21). Descriptive statistics were presented as frequencies. Age was categorized into five groups: $(\leq 20),(21-30),(31-40),(41-$ $50)$ and (>50). Cross-tabulation between HSV-1 serostatus and demographic data were performed, the differences were examined by the Chi-square test $\left(X^{2}\right.$-test) or Fisher's exact test wherever appropriate. Correlations between variables were estimated by using Pearson's correlation ( $r$ ). Statistical significance was considered at a $P$ value equal or less than 0.05 .

\section{RESULTS}

In current study, frequency of anti HSV1 IgG Ab were found in 427 out of 454 (94.1\%). The age group of (21-30) years had the highest percentage of seropositivity for anti HSV-1 IgG $\mathrm{Ab}(39.1 \%)$ followed by the age group of (31-40) with seropositivity for anti HSV-1 IgG Ab (32.3\%), while age group ( $>50$ ) years had the lowest seropositivity (4.4\%) followed by the age group of $(\leq 20)$ with seropositivity for anti HSV-1 IgG Ab (5.4\%), however, there was no significant association in HSV-1 IgG Ab positivity among different age group $\left(\chi^{2}=8.496, P>0.05\right)$. Moreover there was a significant positive correlation between the HSV-1 IgG Ab seropositivity and the extend of age $(r=0.127, P<0.05)$, as shown in table (1).

Table 1. HSV-1 Seroprevalences in Iraqi healthy blood donors, grouped according to age.

\begin{tabular}{llll}
\hline \multirow{2}{*}{$\begin{array}{l}\text { Age } \\
\text { Group }\end{array}$} & \multicolumn{2}{c}{ HSV1-IgG } & \multirow{2}{*}{ Total } \\
\cline { 2 - 3 } & Negative & Positive & \\
\hline 20 & $2(7.4 \%)$ & $23(5.4 \%)$ & $25(5.5 \%)$ \\
$21-30$ & $17(63.0 \%)$ & $167(39.1 \%)$ & $184(40.5 \%)$ \\
$31-40$ & $7(25.9 \%)$ & $138(32.3 \%)$ & $145(31.9 \%)$ \\
$41-50$ & $1(3.7 \%)$ & $80(18.7 \%)$ & $81(17.8 \%)$ \\
$>50$ & $0(0.0 \%)$ & $19(4.4 \%)$ & $19(4.2 \%)$ \\
Total & $27(100.0 \%)$ & $427(100.0 \%)$ & $454(100.0 \%)$ \\
\hline
\end{tabular}

* Chi-square $\left(\chi^{2}\right)=8.496, P=0.075$

** Pearson Correlation $(r)=0.127, P=0.007$

This study showed that the frequency of HSV-1 IgG Ab seropositivity were (15.2\%) in female and $(84.8 \%)$ in male with no statistically significant differences between male and female in the acquiring of HSV-1 Ab (Fisher's Exact Test, $P>0.05$ ), as shown in table (2).

Table 2. HSV-1 Seroprevalences in Iraqi healthy blood donors, grouped according to gender

\begin{tabular}{llll}
\hline \multirow{2}{*}{ Gender } & \multicolumn{2}{c}{ HSV1-IgG } & \multirow{2}{*}{ Total } \\
\cline { 2 - 3 } & Negative & Positive & \\
\hline Female & $4(14.8 \%)$ & $65(15.2 \%)$ & $69(15.2 \%)$ \\
Male & $23(85.2 \%)$ & $362(84.8 \%)$ & $385(84.8 \%)$ \\
Total & $27(100.0 \%)$ & $427(100.0 \%)$ & $454(100.0 \%)$
\end{tabular}

*Fisher's Exact Test $P$ value $=0.9999$

**Pearson Correlation $(r)=0.003, P=0.954$ 
According to occupation, the anti HSV1 antibody seropositivity were more in those working in private sector (54.6\%) while the less prevalent in student $(5.4 \%)$, however, there was no significant difference between anti HSV-IgG $A b$ positive and negative groups regarding to the occupation ( $\left.X^{2}=0.966, P>0.05\right)$, as shown in table (3).

Table 3. HSV-1 Seroprevalences in Iraqi healthy blood donors, grouped according to occupation

\begin{tabular}{lccc}
\hline \multirow{2}{*}{ Occupation } & \multicolumn{2}{c}{ HSV1-IgG } & Total \\
\cline { 2 - 3 } & Negative & Positive & \\
\hline Private & 16 & 233 & 249 \\
sector & $(59.3 \%)$ & $(54.6 \%)$ & $(54.8 \%)$ \\
Governmental & 5 & 74 & 79 \\
employee & $(18.5 \%)$ & $(17.3 \%)$ & $(17.4 \%)$ \\
Military & 2 & 56 & 58 \\
& $(7.4 \%)$ & $(13.1 \%)$ & $(12.8 \%)$ \\
Student & 1 & 23 & 24 \\
& $(3.7 \%)$ & $(5.4 \%)$ & $(5.3 \%)$ \\
House wife & 3 & 41 & 44 \\
& $(11.1 \%)$ & $(9.6 \%)$ & $(9.7 \%)$ \\
Total & 27 & 427 & 454 \\
& $(100.0 \%)$ & $(100.9 \%)$ & $(100.0 \%)$ \\
& & &
\end{tabular}

*Chi-square $\left(\chi^{2}\right)=0.966, P=0.915$

**Pearson Correlation $(r)=0.016, P=0.726$

This study revealed that $(70.7 \%)$ of those with positive serology had no history of travel and (29.3\%) of them had a history of travel, although there was no significant differences in acquisition of HSV-1 antibodies regarding the travel history (Fisher's Exact Test, $P>0.05$ ), as shown in table (4).

Cupping practice was included in this study to estimate wither there is an association with HSV-1 seropositivity. Herpes Simplex Virus

Table 4. HSV-1 Seroprevalences in Iraqi healthy blood donors, grouped according to travel history

\begin{tabular}{llll}
\hline \multirow{2}{*}{$\begin{array}{l}\text { Travel } \\
\text { History }\end{array}$} & \multicolumn{2}{c}{ HSV1-IgG } & \multirow{2}{*}{ Total } \\
\cline { 2 - 3 } & Negative & Positive & \\
\hline No & $19(70.4 \%)$ & $302(70.7 \%)$ & $321(70.7 \%)$ \\
Yes & $8(29.6 \%)$ & $125(29.3 \%)$ & $133(29.3 \%)$ \\
Total & $27(100 \%)$ & $427(100 \%)$ & $454(100 \%)$ \\
\hline
\end{tabular}

*Fisher's Exact Test $P$ value $=0.9999$

**Pearson Correlation $(r)=-0.002, P=0.969$ type 1 IgG was observed in (71.7\%) and (28.3\%) among those who did not practice cupping and those who practice cupping with no statistically significant differences between both groups (Fisher's Exact Test $P>0.05$ ), as shown in table (5).

Table 5. HSV-1 Seroprevalences in Iraqi healthy blood donors, grouped according to cupping practice

\begin{tabular}{llll}
\hline \multirow{2}{*}{$\begin{array}{llll}\text { Cupping } \\
\text { practice* }\end{array}$} & \multicolumn{2}{c}{ HSV1-IgG* } & Total \\
\cline { 2 - 3 } & Negative & Positive & \\
\hline No & $22(81.5 \%)$ & $306(71.7 \%)$ & $328(72.2)$ \\
Yes & $5(18.5 \%)$ & $121(28.3 \%)$ & $126(27.8)$ \\
Total & $27(100 \%)$ & $427(100 \%)$ & $454(100 \%)$ \\
\hline
\end{tabular}

*Fisher's Exact Test $P$ value $=0.376$

**Pearson Correlation $(r)=0.039, P=0.406$

\section{DISCUSSION}

HSV-1 infection is widespread, and its seropositivity may cover more than $70 \%$ of the world population. In the United States, $65 \%$ of people have HSV-1 antibodies, which is comparable to the epidemiology in Europe ${ }^{1}$. The variation of HSV-1 prevalence has been related to the diversity of socioeconomic conditions ${ }^{9}$. In the Middle East and North Africa (MENA), seroprevalence was $65.2 \%$ in children, and $91.5 \%$ in adults ${ }^{7}$. The present study showed that the prevalence rate for HSV-1 IgG antibody was (94.1\%) (Table 1) which is nearby to that reported by Hossain (1989) who found that the overall prevalence of HSV-1 IgG antibody in adult were $(90 \%)^{9}$, but it is in contrast to a study that conducted in Baquba-Iraq in two different groups (students and outpatient with different skin disease other than HSV infection) that reported the seroprevalence of HSV-1 IgG Ab and HSV-2 IgG Ab was (56.51\%) and (43.45\%), respectively, although the same study showed that $(79.09 \%)$ were positive for HSV IgG Ab in general ${ }^{17}$. This may be due to cross-reactivity for the two Herpes serotypes HSV-1 and HSV-2 ${ }^{16}$ or due to using different diagnostic methods that may differ in sensitivity and specificity ${ }^{18,19}$ or due to differences in the populations studied ${ }^{20}$. Other study demonstrated that the seroprevalence of HSV-1 IgG Ab among blood donors living in Qatar was $80.5 \%$ among Palestinians, $81.4 \%$ among Lebanese, $81.4 \%$ among Iranians, $82.3 \%$ among 
Qataris, 86.5\% among Jordanians, 88.5\% among Syrians, $90.7 \%$ among Sudanese, $92.6 \%$ among Yemenis and the higher prevalence was $97.5 \%$ among Egyptians ${ }^{6}$.

Regarding to age and gender, the current finding of the frequency of HSV-1 IgG Ab was higher in age groups (21-30) and (31-40) years with no significant differences between males and females (Table 1 and Table 2), which close to that demonstrated by Al-Kayalli et al. (2015) who found that HSV infection was predominantly in age group (21-40 years $)^{17}$. However, in Saudi Arabia, a study reported that the prevalence of HSV-1 IgG showed a progressive increase with age in both males and females with no obvious sex-related variation ${ }^{9}$. Another study have reported a small increase in the seroprevalence of HSV-1 Ab and HSV-2 Ab above the age of 40 years ${ }^{21}$. Despite the fact that our specimens were not completely representative of the general population (385 were male while only 69 were female), however, the results about age and gender dispersion aren't affected by this. Chaabane et al. (2019) mentioned that age and country's income could explained half of the variation of HSV-1 seroprevalence. While other factors such as gender, population type, year of publication, sample number technique used, were not significantly associated with sero-prevalence ${ }^{7}$. In addition, the existing evidence suggests that was no major sex-specific differences ${ }^{21,20,22,23,24}$ and the sample collection bias may be less important for HSV-1, as the virus is primarily orally transmitted within a general-population ${ }^{6}$.

According to occupation, the current study showed a higher seroprevalence of HSV-1 were found in those working in private sector $(54.6 \%)$, while the lower seroprevalence were found in students (5.4\%), however there was no significant association between occupation and HSV-1 positivity (Table 3). Interestingly, Al-Kayalli et al. (2015) mentioned that the prevalence of HSV Ab were more in student (33.4\%) and less prevalent in those working in private sector (19\%) although however it was statistically not significant ${ }^{17}$. The current finding of HSV-1 IgG $\mathrm{Ab}$ in Governorate worker were (17.3\%) which is comparable to that report by other ${ }^{17}$. This suggested that HSV-1 existence is high in Iraqi population with no declines in frequency in spite of increasing the income of Iraqi people after the end of the economic siege as the younger person (21-40 years) had higher HSV-1 seroprevalence than older person ( $>50$ years). The route of transmission of HSV-1 is by close contact either sexually or non sexually and infections are acquired during childhood and adolescence. Approximately fifty percent of isolated herpes from hands, fingers and extra-genital regions other than oro-facial area were belong to HSV type-1 while the remaining were belong to HSV type $-2^{15}$.

This study showed that there was no significant association between travel history or cupping practice and HSV-1 IgG positivity (Table 4 and Table 5). Researcher found that different HSV-1 strains in a single individual can be used as a record of the person's travel history. In addition, viral DNA sequencing may someday become a useful forensic tool and could serve as a surrogate biomarker to study human population structure and migration patterns ${ }^{25,26}$. Regarding cupping which is a traditional oriental medicine, a study conducted in Korea have reported an uncommon case of cutaneous herpes infection that suspected to be a consequence of cupping due to direct viral inoculation via contamination or HSV reactivation due to mechanical trauma ${ }^{27}$.

Herpes simplex virus type 1 causes a various diseases such as neonatal herpes, corneal blindness, meningitis, encephalitis and genital herpes $^{7}$. The fact of the high frequency of HSV-1 IgG Ab in our population suggests that the HSV-1 morbidity should be quantified and addressed. In addition, it is highlight the importance of increasing the effort for vaccine development.

\section{ACKNOWLEDGMENTS}

We would like to express our heartfelt thanks to all the staff members in Blood Donation Center in Al-Imamain Al-Kadhimain Medical City Hospital and The National Blood Bank for their assistance in samples collection. Thanks to Asst. Prof. Dr. Ghaith Ali Jasim for providing assistance on statistical analysis. This study was financial supported by L'Oreal-UNESCO for Women in Science Levant and Egypt.

\section{CONFLICT OF INTEREST}

The authors declare that there is no conflict of interest. 


\section{AUTHOR'S CONTRIBUTION}

AMA, DBH and ZQA designed the study and developed the research methodology. AMA and $\mathrm{DBH}$ provided the specimens. AMA conducted laboratory work on the specimens and wrote the initial draft of the article. All authors contributed to the interpretation of the results and drafting and revision of the article.

\section{FUNDING}

Dr. Arwa Mujahid was financially supported by L'Oreal- UNESCO "for women in science 2017" Levant and Egypt regional fellowship.

\section{DATA AVAILABILITY}

All datasets generated or analyzed during this study are included in the manuscript and/or the Supplementary Files.

\section{ETHICS STATEMENT}

This study was approved by Institutional Review Board (IRB) at Al-Nahrain College of Medicine number \#210.

\section{REFERENCES}

1. Zhang J., Liu H., Wei B. Immune response of T cells during herpes simplex virus type 1 (HSV-1) infection. J. Zhejiang Univ-Sci. B (Biomed \& Biotechnol), 2017; 18(4): 277-288.

2. Roizman B., Whitley R.J. The nine ages of herpes simplex virus. Herpes., 2001; 8(1): 23-27.

3. Xu F., Sternberg M.R., Kottiri B.J., McQuillan G.M., Lee F.K., Nahmias A.J., Berman S.M., Markowitz L.E. Trends in herpes simplex virus type 1 and type 2 seroprevalence in the United States. JAMA, 2006; 296(8): 964-73.

4. Tayyebi D., Sharifi S. Seroepidemiology of infection with herpes simplex virus types 1 and 2 (HSV1 and HSV2) among asymptomatic university students attending Islamic Azad University of Kazeroun, southwest of Iran. Iranian Journal of Clinical Infectious Diseases, 2010; 5(2): 84-88.

5. Schiffer J.T., Mayer B.T., Fong Y., Wald A. and Swan, D.A. Herpes simplex virus transmission probability estimates based on quantity of viral shedding. J.R. Socio Interface, 2014; 11(95): 20140-160.

6. Nasrallah G.K., Dargham S.R., Mohammed L.I., AbuRaddad L.J. Estimating seroprevalence of herpes simplex virus type 1 among different Middle East and North African male populations residing in Qatar. J. Med. Virol., 2018; 90: 184-190.

7. Chaabane S., Harfouche M., Chemaitelly H., Schwarzer G., Abu-Raddad L.J. Herpes simplex virus type 1 epidemiology in the Middle East and North
Africa: systematic review, meta-analyses, and metaregressions. Scientific Reports, 2019; 9: 1136.

8. Corey L. and Wald A. Maternal and neonatal HSV infections. New England Journal of medicine, 2009; 361(14): 1376-85.

9. Hossain A. Herpes Simplex Virus Type 1 (HSV-1) and Varicellazoster Virus (VZV) Infections in Saudi Arabia. Journal of Tropical Pediatrics, 1989; 35: 171- 174.

10. Nicoll M.P., Proenca J.T., Efstathiou S. The molecular basis of herpes simplex virus latency. FEMS Microbiol. Rev., 2012; 36(3): 684-705.

11. Wuest T.R. and Carr D.J. The role of chemokines during herpes simplex virus-1 infection. Front Biosci., 2008; 13: 4862-4872.

12. Simoons A.M., Kraan E.M., Beishuizen A., Strack van Schijndel R.J. and Vander broucke-Grauls C.M. Herpes simplex virus type 1 and respiratory disease in critically-ill patients: real pathogen or innocent bystander? Clinical Microbiology and Infection, 2006; 12(11): 1050-1059.

13. Zangana L.M.M. Seroprevalence of Herpes Simplex Virus type-1antibodies (IgM, IgG) in smokers in Kirkuk city-Iraq. Tikrit Journal of Pure Science, 2016; 21(1): 36-40.

14. Chayavichitsilp P., Buckwalter J.V., Krakowski A.C. and Fried lander SF. Herpes simplex. Journ Pediatr. Rev., 2009; 30(4): 119-29.

15. Kasubi M.J., Nilsen A., Marsden H.S., Bergstrom T., Langeland N. and Haarr L. Prevalence of Antibodies against Herpes Simplex Virus Types 1 and 2 in Children and Young People in an Urban Region in Tanzania. Journal of Clinical Microbiology, 2006; 44(8): 28012807.

16. Smith H.G., Horowitz N., Silverman N.A., Henson D.E., Chretien P.B. Humoral immunity to herpes simplex viral-induced antigens in smokers. Cancer, 1976; 38(3): 1155-62.

17. Al-Kayalli K.K.I., Al-Azawy M.K.K., Al-Azawy A.T.N. Evaluation of Seroprevalence of Herpes Simplex Virus IgG Antibody in Baquba City by using ELISA Technique. Diyala Journal For Pure Science, 2015; 11(2): 99-108.

18. Ashley R.L. Performance and use of HSV type-specific serology test kits. Herpes, 2002; 9: 38-45.

19. Ashley-Morrow R., Nollkamper J., Robinson N.J., Bishop N., Smith J. Performance of focus ELISA tests for herpes simplex virus type 1 (HSV-1) and HSV-2 antibodies among women in ten diverse geographical locations. Clin. Microbiol. Infect., 2004; 10: 530-536.

20. Costa Clemens S.A., Farhat C.K. Seroprevalence of herpes simplex 1-2 antibodies in Brazil. Rev Saתde $P$ ת blica, 2010; 44(4): 1-8.

21. Smith J.S., Robinson J.N. Age-specific prevalence of infection with herpes simplex virus type1 and 2: a global review. J. Infect. Dis., 2002; 186(Suppl.1): S3S28.

22. Igde F.A., Igde M. Seroepidemiological Study of Herpes Simplex Virus Type 1 in the Black Sea Region of Turkey. Balkan. Med. J., 2011; 28: 37-42.

23. Looker K.J., Magaret A.S., May M.T., et al. Global and regional estimates of prevalent and incident herpes simplex virus type 1 infections in 2012. PLOS ONE, 
2015; 10: e0140765.

24. Malary M., Abedi G., Hamzehgardeshi Z., Afshari M., Moosazadeh $M$. The prevalence of herpes simplex virus type 1 and 2 infection in Iran: A meta-analysis. Int. J. Reprod BioMed., 2016; 14(10): 615-624.

25. Kolb A.W., Ane' C., Brandt C.R. Using HSV-1 Genome Phylogenetics to Track Past Human Migrations. PLOS ONE, 2013; 8(10): e76267.
26. Bowen C.D., Renner D.W., Shreve J.T., Tafuri Y., Payne KM, Dix RD, Kinchington PR, Gatherer D, Szpara ML. Viral forensic genomics reveals the relatedness of classic herpes simplex virus strains KOS, KOS63, and KOS79. Virology, 2016; 492: 179-186.

27. Jung Y.-J., Kim J.-H., Lee Hae-Jin, Bak H., Hong S.P., Jeon S.Y., Ahn S.K. A Herpes Simplex Virus Infection Secondary to Acupuncture and Cupping. Ann. Dermatol., 2011; 23(1): 67- 69. 